\title{
Effect of bovine ABCG2 Y581S polymorphism on concentrations in milk of enrofloxacin and its active metabolite ciprofloxacin
}

\author{
J. A. Otero, ${ }^{*} \dagger$ D. García-Mateos, ${ }^{*}$ A. de la Fuente, ${ }^{*}$ J. G. Prieto, ${ }^{\star} \ddagger$ A. I. Álvarez, ${ }^{*}$ and G. Merino ${ }^{*} \dagger^{1}$ \\ ${ }^{*}$ Department of Biomedical Sciences-Physiology, Veterinary Faculty, and \\ †Instituto de Desarrollo Ganadero y Sanidad Animal (INDEGSAL), and \\ łInstituto de Biomedicina (IBIOMED), University of Leon, Campus de Vegazana 24071, Leon, Spain
}

\section{ABSTRACT}

The ATP-binding cassette transporter G2 (ABCG2) is involved in the secretion of several drugs into milk. The bovine Y581S ABCG2 polymorphism increases the secretion into milk of the fluoroquinolone danofloxacin in Holstein cows. Danofloxacin and enrofloxacin are the fluoroquinolones most widely used in veterinary medicine. Both enrofloxacin (ENRO) and its active metabolite ciprofloxacin (CIPRO) reach milk at relatively high concentrations. The aim of this work was to study the effect of the bovine Y581S ABCG2 polymorphism on in vitro transport as well as on concentrations in plasma and in milk of ENRO and CIPRO. Experiments using cells overexpressing bovine ABCG2 showed the effects of ABCG2 on the transport of CIPRO, demonstrating more efficient in vitro transport of this antimicrobial by the S581 variant as compared with the Y581 variant. Animal studies administering $2.5 \mathrm{mg} / \mathrm{kg}$ of ENRO subcutaneously to $\mathrm{Y} / \mathrm{Y} 581$ and Y/S 581 cows revealed that concentrations in plasma of ENRO and CIPRO were significantly lower in Y/S animals. Regardless of the genotype, the antimicrobial profile in milk after the administration of ENRO was predominantly of CIPRO. With respect to the genotype effects on the amounts of drugs present in milk, $\mathrm{AUC}_{0-24}$ values were more than 1.2 times higher in $\mathrm{Y} / \mathrm{S}$ cows for ENRO and 2.2 times for CIPRO, indicating a greater capacity of Y581S to transfer these drugs into milk. These results emphasize the clinical relevance of this polymorphism as a factor affecting the concentrations in plasma and in milk of drugs of importance in veterinary medicine.

Key words: bovine ABCG2, polymorphism, enrofloxacin, ciprofloxacin

Received November 4, 2015.

Accepted March 24, 2016.

${ }^{1}$ Corresponding author: gmerp@unileon.es

\section{INTRODUCTION}

Enrofloxacin (ENRO) and its active metabolite ciprofloxacin (CIPRO) are broad-spectrum antimicrobials belonging to the group of fluoroquinolones. Enrofloxacin was developed for veterinary use and is indicated for the treatment of many diseases in cattle, including respiratory and alimentary tract diseases of bacterial or mycoplasmal origin and mastitis (LopezCadenas et al., 2013). It is widely distributed throughout the organism, with excellent tissue penetration and a long serum half-life. Both drugs, ENRO and CIPRO, reach high concentrations in milk (Kaartinen et al., 1995). Antimicrobial treatment of dairy cows creates residues in milk, and the avoidance of such residues is an important aspect of mastitis treatment (Pyörälä, 2009). At the present time, residues in milk of drugs administered to livestock pose a growing concern because of financial losses and the potential selection of antibiotic-resistant bacteria if dairy products that contain residues reach consumers (Virolainen and Karp, 2014). Although adherence to instructions on labeling relative to withdrawal periods is the principal step in controlling drug residues in milk, a knowledge of the factors involved in the secretion of drugs into milk may also be of assistance in overcoming this difficulty.

Several fluoroquinolones such as CIPRO or danofloxacin have been reported to be secreted into milk by the ATP-binding cassette transporter G2 (ABCG2) in experiments using $A b c g 2$ knockout mice, contributing to the high concentrations of these antimicrobials in milk (Merino et al., 2006; Real et al., 2011a). The superfamily of $\mathrm{ABC}$ transporters consists of a group of proteins that usually play a protective role in cells and tissues against toxic compounds and limit organism exposure to potentially harmful molecules (Petzinger and Geyer, 2006). Several in vivo studies have indicated that ABCG2 mediates intestinal, hepatobiliary, and renal excretion of its substrates (reviewed by Jani et al., 2014) affecting drug efficacy, drug-drug interactions, and adverse effects from drugs (Ballent et al., 
2012; Mealey, 2013). Jonker et al. (2005) showed that expression of ABCG2 in the mammary gland is induced during lactation and plays an important role in the secretion of drugs into mouse milk. Although this induction is not exclusive to this $\mathrm{ABC}$ transporter in the lactating mammary gland (Mani et al., 2009; Ito et al., 2014), a major role for ABCG2 in the secretion of antimicrobials into the milk of ruminants has also been reported (Real et al., 2011a; Mealey, 2013).

Enrofloxacin was the first veterinary fluoroquinolone to be identified as an in vitro substrate of ABCG2 (Pulido et al., 2006; Wassermann et al., 2013a). Administration of ENRO in vivo jointly with ABCG2 inhibitors decreased ENRO concentrations in sheep milk (Pulido et al., 2006). In cattle, the genetic variant Y581S ABCG2 (rs43702337) has been described as an in vitro and in vivo gain-of-function polymorphism with a greater capacity to transport compounds in vitro, including ENRO and danofloxacin (Real et al., 2011b). Administration of danofloxacin to cows carrying the Y581S polymorphism resulted in higher concentrations in milk of this fluoroquinolone in comparison with the results in wild-type animals (Otero et al., 2013, 2015).

In the present study, we assessed the differential in vitro transport of CIPRO by both variants of the Y581S polymorphism using cells overexpressing bovine ABCG2. The effect of this polymorphism on the concentrations in plasma and in milk of ENRO and of CIPRO was also investigated by administering ENRO to $\mathrm{Y} / \mathrm{Y} 581$ and $\mathrm{Y} / \mathrm{S} 581$ cows.

\section{MATERIALS AND METHODS}

\section{Reagents and Drugs}

The CIPRO used in cell cultures was obtained from Sigma-Aldrich (St. Louis, MO). Baytril (ENRO 10\%) was purchased from Bayer (Barcelona, Spain) for use in the in vivo studies. The specific ABCG2 inhibitor Ko143 was obtained from Tocris (Bristol, UK). All the other chemicals were analytical grade and available from commercial sources.

\section{Cell Cultures}

Madin-Darby canine kidney epithelial cell (MDCKII) parental cells were provided by A. H. Schinkel (Netherlands Cancer Institute, Amsterdam). The MDCK-II cells stably transduced with both bovine variants (S581 and Y581) of ABCG2 had previously been generated and characterized by the research group (Real et al., 2011b). These transduced cells express bABCG2 protein at similar levels and the polymorphism had no effect on transporter trafficking to the cell surface (Real et al., 2011b). Cell culture conditions were the same as those described by González-Lobato et al. (2014); briefly, cells were cultured at $37^{\circ} \mathrm{C}$ and $\mathrm{pH}$ 7.4 in an atmosphere with $5 \% \mathrm{CO}_{2}$ in Dulbecco's modified Eagle medium with GlutaMAX (Life Technologies Inc., Carlsbad, CA), supplemented with $10 \%$ fetal calf serum (Life Technologies), penicillin $(50 \mathrm{U} / \mathrm{mL})$, and streptomycin $(50 \mu \mathrm{g} / \mathrm{mL}$; Life Technologies $)$.

\section{Transport Studies}

Transepithelial transport assays using Transwell plates were carried out as described elsewhere (Perez et al., 2013) with minor modifications. Cells were seeded on microporous polycarbonate membrane filters (3.0 $\mu \mathrm{m}$ pore size, $24 \mathrm{~mm}$ diameter; Transwell 3414, Corning, NY) at a density of $1.0 \times 10^{6}$ cells per well. Cells were grown for $3 \mathrm{~d}$, and the medium was replaced each day. To check the tightness of the monolayer, transepithelial resistance was measured in each well using a Millicell ERS ohmmeter (Millipore, Bedford, MA). After corrections had been made for the resistance obtained in blank control wells, those wells that registered a resistance of $200 \mathrm{ohms}$ or greater were used in the transport experiments.

Before the start of the experiment, the medium on both sides of the monolayer was replaced with $2 \mathrm{~mL}$ of Optimem medium (Life Technologies Inc.), free of serum, and either containing or not the specific ABCG2 inhibitor $1 \mu M \mathrm{Ko} 143$, for $2 \mathrm{~h}$. After incubation, the experiment was started $(t=0)$ by replacing the medium in either the apical or basolateral compartment with fresh Optimem medium containing $1 \mu M$ CIPRO, with or without the inhibitor $1 \mu M$ Ko143. Aliquots of $100 \mu \mathrm{L}$ were taken from the opposite compartment, after 2 and $4 \mathrm{~h}$ of incubation, and stored at $-20^{\circ} \mathrm{C}$ until HPLC analysis could be undertaken. At least 3 replicates of each setting were performed. The fraction of CIPRO transported to the acceptor compartment was presented as a percentage of the total amount of CIP$\mathrm{RO}$ added to the donor compartment at the beginning of the experiment. Active transport across MDCK-II monolayers was expressed as the relative transport ratio, defined as the apically directed transport percentage divided by the basolaterally directed translocation percentage, after $4 \mathrm{~h}$. The relative transport ratio at $4 \mathrm{~h}$ is a parameter that has previously been used for comparison purposes in transport assays (Barrera et al., 2013; Moreno-Sanz et al., 2014).

\section{Animal Studies}

Animals were handled in accordance with institutional guidelines that complied with European legislation 
(2010/63/EU). The experiments were approved by the Research Committee for Animal Use of the University of Leon (approval number 13-2011, date of approval 7 November 2011).

Lactating Holstein-breed cows aged between 2 and 5 yr and weighing 650 to $830 \mathrm{~kg}$ were used. Their daily milk yield was on average $45 \pm 8 \mathrm{~kg}$. No difference was found in age, weight, or milk yield between the 2 sets of cows. The normal milking routine for all the animals involved milk being taken twice each day. The experiments were performed at a private farm located at Santa María del Monte del Condado, Leon (Spain). The Y581S genotypes were determined in accordance with the procedure described by Komisarek and Dorynek (2009). During the genotyping procedure, S/S animals could not be found. Animals were divided into 2 groups of $5 \mathrm{Y} / \mathrm{S} 581$ heterozygous and $6 \mathrm{Y} / \mathrm{Y} 581$ homozygous cows. Immediately before the administration of the drug (time 0), the animals were milked, which coincided with their routine morning milking. Both groups received a single dose of $2.5 \mathrm{mg} / \mathrm{kg}$ of ENRO subcutaneously (Baytril 10\%, Bayer). Blood samples were collected from the tail vein at 1, 5, 11, 24, and 48 $\mathrm{h}$ after treatment. Milk samples were collected manually at 1, 2, 5, 11 (the routine afternoon milking), 24, and $48 \mathrm{~h}$ after treatment. A complete evacuation of the udder was carried out at each sampling to avoid any dilution effect. Plasma was separated by centrifugation at $1,000 \times g$ for $15 \mathrm{~min}$, and plasma and milk samples were stored at $-20^{\circ} \mathrm{C}$ until HPLC analysis.

\section{HPLC Analysis}

The conditions for HPLC analysis of ENRO and CIPRO concentration from transport assays and pharmacokinetic studies in cows were based on Perez et al. (2013) and Barrera et al. (2013). Danofloxacin $(0.01 \mu \mathrm{g} / \mathrm{mL})$ for the plasma analysis and difloxacin $(0.01 \mu \mathrm{g} / \mathrm{mL})$ for the milk analysis were used as internal standards. Then $600 \mu \mathrm{L}$ of chloroform was added to each $100-\mu \mathrm{L}$ aliquot of sample, which was shaken for $30 \mathrm{~min}$ and centrifuged at $5,000 \times g$ for $6 \mathrm{~min}$ at room temperature. The organic phase was separated and evaporated until dry in a stream of nitrogen. The residue was reconstituted in $100 \mu \mathrm{L}$ of methanol and injected into the HPLC system. Samples from the transport assays were not extracted with chloroform, with $50 \mu \mathrm{L}$ of the culture medium injected directly into the HPLC system. The system consisted of a Waters 600 pump, a Waters 717 plus autosampler, a Waters 486 fluorescence detector (Waters Corporation, Milford, MA), and a C18 reversed-phase column (Mediterranea Sea 18, $5 \mu \mathrm{m} 25 \times 0.46 \mathrm{~cm}$; Teknokroma, Barcelona, Spain). The mobile phase consisted of $25 \mathrm{~m} M$ ortho- phosphoric acid supplemented with $0.1 \%$ triethylamine (pH 3.0):acetonitrile $(87: 13)$. The flow rate was set up at $1.25 \mathrm{~mL} / \mathrm{min}$. Fluorescence was detected at $280 \mathrm{~nm}$ (excitation) and $460 \mathrm{~nm}$ (emission). Integration was performed using Millennium 32 software (Waters). The limit of quantification values in plasma were $3.9 \mathrm{ng} / \mathrm{mL}$ for ENRO and $7.8 \mathrm{ng} / \mathrm{mL}$ for CIPRO, and in milk 7.8 $\mathrm{ng} / \mathrm{mL}$ for both ENRO and CIPRO.

\section{Pharmacokinetic Analysis}

Plasma and milk concentrations for each animal were analyzed using a computer program (PK solution 2.0, Summit Research Services, Ashland, OH). Peak concentrations $\left(\mathbf{C}_{\max }\right)$ and time-peak concentrations $\left(\mathbf{T}_{\max }\right)$ were read from the plotted concentration-time curve for each animal. The area under the plasma concentration-time curves $\left(\mathrm{AUC}_{0-\rightarrow \infty}\right)$ was calculated using the linear trapezoidal rule from time zero with extrapolation to time infinity. The drug mean residence time (MRT) was calculated by the linear trapezoidal rule with extrapolation to time infinity, using the formula: $\mathrm{MRT}=\mathrm{AUMC} / \mathrm{AUC}$, where AUMC is the mean area under the momentum curve.

\section{Statistical Analysis}

Statistical analysis for significant differences was performed using the 2-tailed Student's $t$-test. Results are reported as mean values $\pm \mathrm{SD}$. A probability of $P<$ 0.05 was considered to be statistically significant.

\section{RESULTS}

\section{In Vitro Transport of CIPRO}

To determine whether the bovine ABCG2 variants could transport CIPRO differentially, transport assays were performed using polarized MDCK-II parental cells and their transduced subclones with both bovine ABCG2 variants (S581 and Y581). These cells with the protein located on the apical membrane preferentially transported ABCG2 substrates to the apical site.

Basal-to-apical transport of CIPRO was strongly increased in the $b A B C G$ 2-transduced subclones, as compared with parental MDCK-II cells (Figure 1A-C), indicating a specific transport of CIPRO by bovine ABCG2, thanks to its apical location. Moreover, the relative transport ratio (i.e., the apical directed translocation divided by the basolateral directed translocation at $t=4 \mathrm{~h}$ ) was higher for the S581 variant, as compared with the Y581 variant $(1.70 \pm 0.22$ vs. $1.41 \pm 0.11, P<$ $0.05)$, thus showing a greater capacity of the first variant to transport CIPRO. In all cases, bovine ABCG2- 
A

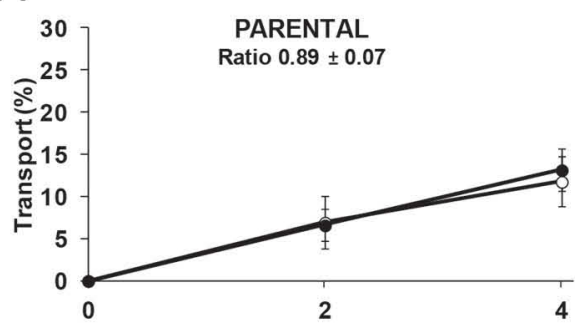

D

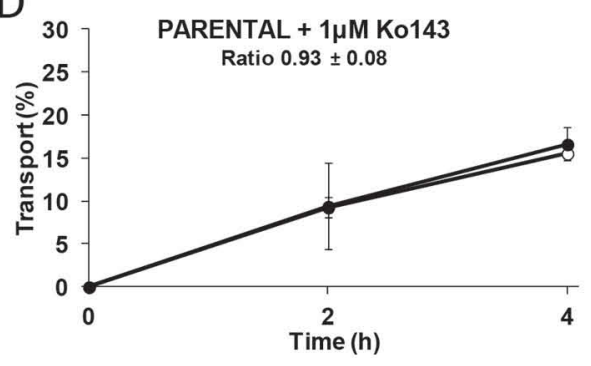

B

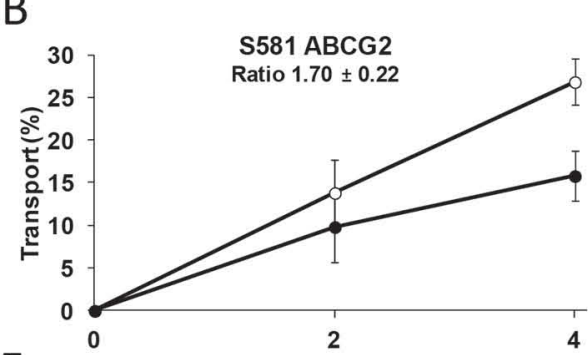

E

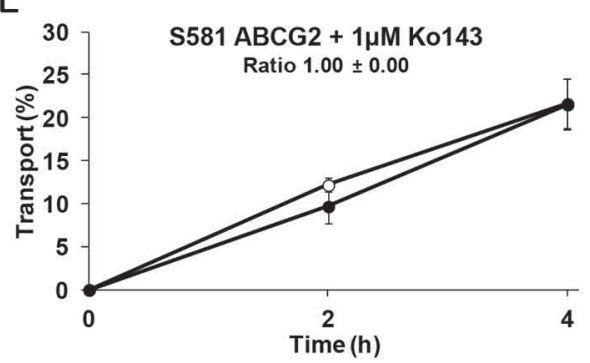

C

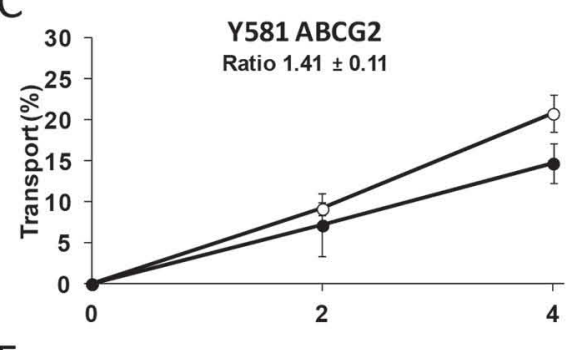

$\mathrm{F}$

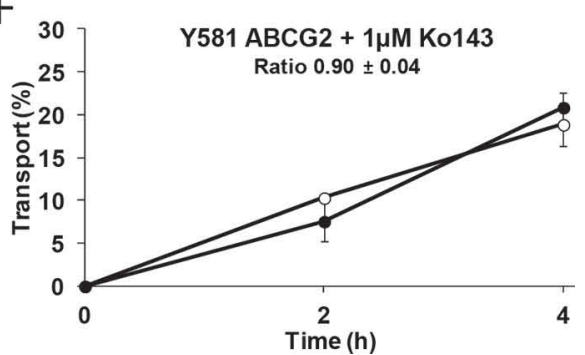

Figure 1. Transepithelial transport of ciprofloxacin (CIPRO; $10 \mu M)$ in polarized Madin-Darby canine kidney epithelial cell (MDCK-II) parental (nontransduced), MDCK-II-S581-ABCG2, and MDCK-II-Y581-ABCG2 monolayers in the absence (A, B, C) or presence (D, E, F) of the specific ATP-binding cassette transporter G2 (ABCG2) inhibitor Ko143 $(1 \mu M)$. The experiment was started $(t=0 \mathrm{~h})$ by replacing the medium in either the apical or basolateral compartment with fresh Optimem medium containing $10 \mu M$ CIPRO, with or without the inhibitor $1 \mu M$ Ko143. Aliquots of $100 \mu \mathrm{L}$ were taken from the opposite compartment at $t=2$ and $4 \mathrm{~h}$ and measured by HPLC. The fraction of CIPRO transported to the acceptor compartment was presented as a percentage of the total amount of CIPRO added to the donor compartment at the beginning of the experiment. Results are means, and error bars indicate SD $(\mathrm{n}=3)$. Ratio represents the relative transport ratio (i.e., the apical directed translocation divided by the basolateral directed translocation) at $t=4 \mathrm{~h}$. $\bigcirc$ Translocation from the basolateral to the apical compartment; translocation from the apical to the basolateral compartment.

mediated transport was completely inhibited with the specific ABCG2 inhibitor Ko143 (Figure 1D-F). These data demonstrated that CIPRO is a substrate of bovine ABCG2 and that the S581 variant transports CIPRO more efficiently than the Y581 variant.

\section{Effects of Y581S Bovine Polymorphism}

To study in more depth the in vivo effect of the Y581S polymorphism on the concentrations in plasma and secretion into milk of ENRO and its main active metabolite CIPRO, plasma and milk concentrations were analyzed after the administration of ENRO at 2.5 $\mathrm{mg} / \mathrm{kg}$ to $\mathrm{Y} / \mathrm{Y} 581$ and $\mathrm{Y} / \mathrm{S} 581$ cows (Figures 2 and $3)$.

Enrofloxacin plasma concentrations at $11 \mathrm{~h}$ after ENRO treatment were significantly lower for $\mathrm{Y} / \mathrm{S}$ $(0.045 \pm 0.008 \mu \mathrm{g} / \mathrm{mL})$ compared with $\mathrm{Y} / \mathrm{Y}$ cows $(0.063 \pm 0.016 \mu \mathrm{g} / \mathrm{mL})$. In the case of CIPRO, significantly smaller concentrations in $\mathrm{Y} / \mathrm{S}$ relative to those obtained in $\mathrm{Y} / \mathrm{Y}$ animals were observed at $5 \mathrm{~h}(0.074 \pm$ $0.010 \mu \mathrm{g} / \mathrm{mL}$ vs. $0.097 \pm 0.019 \mu \mathrm{g} / \mathrm{mL})$ and $11 \mathrm{~h}(0.039$ $\pm 0.007 \mu \mathrm{g} / \mathrm{mL}$ vs. $0.051 \pm 0.008 \mu \mathrm{g} / \mathrm{mL})$. These data indicate that the Y581S polymorphism decreases the concentrations in plasma of these antimicrobials.

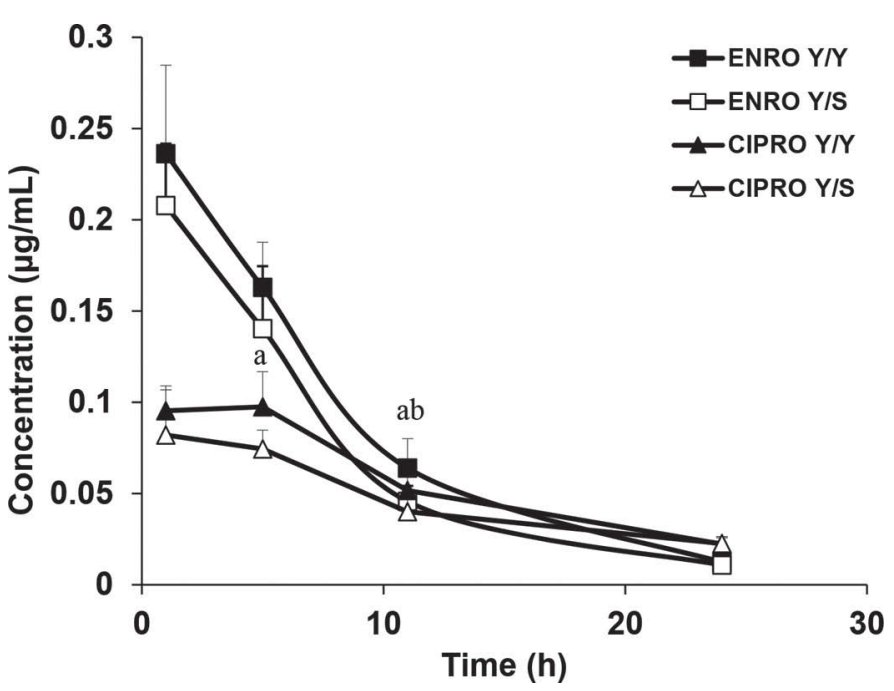

Figure 2. Mean plasma concentrations of enrofloxacin (ENRO) and ciprofloxacin (CIPRO) after subcutaneous administration of ENRO at a dosage of $2.5 \mathrm{mg} / \mathrm{kg}$ to $\mathrm{Y} / \mathrm{S} 581$ and Y/Y 581 lactating cows. Plasma samples were collected at several points over $48 \mathrm{~h}$. Concentrations were undetectable after $48 \mathrm{~h}$. Lowercase letter (a) represents significant differences $(P<0.05)$ between the 2 genotypes for CIPRO. Lowercase letter $(\mathrm{b})$ represents significant differences $(P<0.05)$ between the 2 genotypes for ENRO. $\mathrm{Y} / \mathrm{Y}$ cows $\mathrm{n}=6 ; \mathrm{Y} / \mathrm{S}$ cows $\mathrm{n}=5$. 
With regard to secretion into milk, the area under the milk concentration curve $\left(\mathrm{AUC}_{0-48}\right)$ for ENRO increased significantly in $\mathrm{Y} / \mathrm{S}$ cows and was around 1.2 times higher for $\mathrm{Y} / \mathrm{S}(1.42 \pm 0.24 \mu \mathrm{g} \cdot \mathrm{h} / \mathrm{mL})$ than for $\mathrm{Y} / \mathrm{Y}$ cows $(1.11 \pm 0.14 \mu \mathrm{g} \cdot \mathrm{h} / \mathrm{mL})$, with no differences in $\mathrm{C}_{\max }$ values (Table 1). For CIPRO, concentrations in milk were significantly higher in $\mathrm{Y} / \mathrm{S}$ than in $\mathrm{Y} / \mathrm{Y}$ cows at 5, 11, 24, and $48 \mathrm{~h}$ (Figure 3). The maximum concentration in milk $\left(\mathrm{C}_{\max }\right)$ increased significantly for $\mathrm{Y} / \mathrm{S}(1.03 \pm 0.25 \mu \mathrm{g} / \mathrm{mL})$, as compared with $\mathrm{Y} / \mathrm{Y}$ animals $(0.51 \pm 0.24 \mu \mathrm{g} / \mathrm{mL})$. Milk $\mathrm{AUC}_{0-48}$ for CIPRO was 2 times higher in the cows carrying the Y581S polymorphism $(13.33 \pm 2.26 \mu \mathrm{g} \cdot \mathrm{h} / \mathrm{mL})$ in comparison with noncarriers $(5.94 \pm 2.41 \mu \mathrm{g} \cdot \mathrm{h} / \mathrm{mL}$; Table 1$)$. These results indicate that the Y581S polymorphism increases the amounts of CIPRO and ENRO in milk after the administration of ENRO at $2.5 \mathrm{mg} / \mathrm{kg}$.

\section{DISCUSSION}

It is widely known that genetic variants of human ABCG2 can lead to altered drug pharmacokinetics, affect responses to therapy and clinical outcomes, and be associated with diseases such as gout (Bruhn and Cascorbi, 2014). In the veterinary field, recent research has shown that ABCG2 plays a critical role in drug disposition and safety in animals (Schrickx and Fink-Gremmels, 2008; Mealey, 2012), including its involvement in the secretion of substrate antimicrobi-

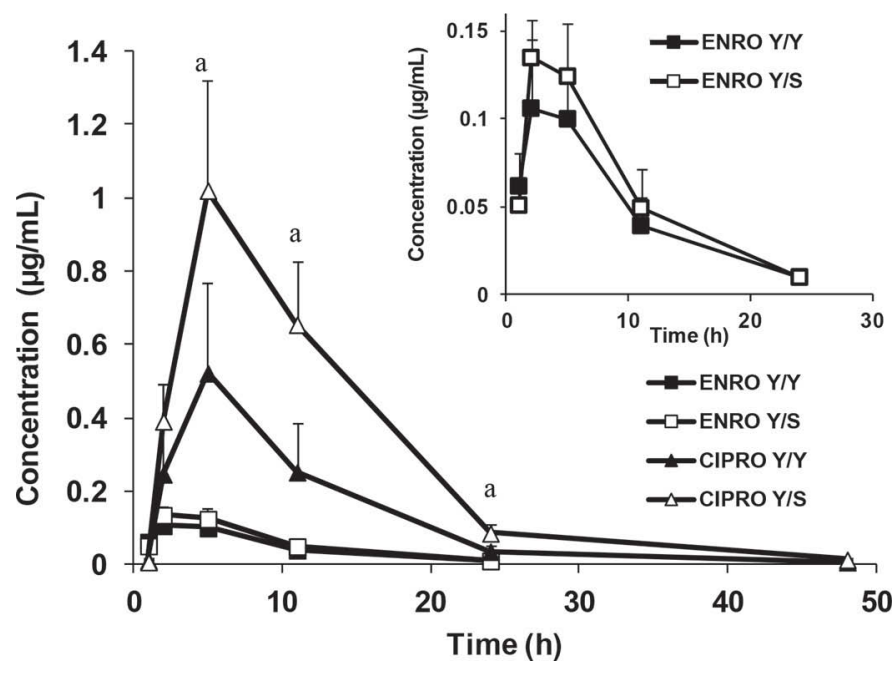

Figure 3. Mean milk concentrations of ENRO and ciprofloxacin (CIPRO) after subcutaneous administration of ENRO at a dosage of $2.5 \mathrm{mg} / \mathrm{kg}$ to $\mathrm{Y} / \mathrm{S} 581$ and $\mathrm{Y} / \mathrm{Y} 581$ lactating cows. The inset shows ENRO data alone. Milk samples were collected at several points over $48 \mathrm{~h}$. Enrofloxacin concentrations were undetectable after $48 \mathrm{~h}$. Lowercase letter (a) represents significant differences $(P<0.05)$ between the 2 genotypes for CIPRO. $\mathrm{Y} / \mathrm{Y}$ cows, $\mathrm{n}=6$; $\mathrm{Y} / \mathrm{S}$ cows, $\mathrm{n}=5$.
Table 1. Pharmacokinetic parameters (means $\pm \mathrm{SD}$ ) for enrofloxacin (ENRO) and ciprofloxacin (CIPRO) in milk after subcutaneous administration of ENRO at a dosage of $2.5 \mathrm{mg} / \mathrm{kg}$ in $\mathrm{Y} / \mathrm{Y}(\mathrm{n}=6)$ and $\mathrm{Y} / \mathrm{S}$ cows $(\mathrm{n}=5)$

\begin{tabular}{|c|c|c|}
\hline Parameter $^{1}$ & Y/Y 581 & Y/S 581 \\
\hline \multicolumn{3}{|l|}{ ENRO } \\
\hline $\mathrm{AUC}_{0-48}(\mu \mathrm{g} \cdot \mathrm{h} / \mathrm{mL})$ & $1.11 \pm 0.14^{\mathrm{a}}$ & $1.42 \pm 0.24^{\mathrm{b}}$ \\
\hline $\operatorname{AUC}_{0-\infty}(\mu \mathrm{g} \cdot \mathrm{h} / \mathrm{mL})$ & $1.23 \pm 0.08^{\mathrm{a}}$ & $1.55 \pm 0.18^{\mathrm{b}}$ \\
\hline $\mathrm{C}_{\max }(\mu \mathrm{g} / \mathrm{mL})$ & $0.11 \pm 0.03$ & $0.13 \pm 0.01$ \\
\hline $\mathrm{T}_{\max }(\mathrm{h})$ & $3.00 \pm 1.41$ & $3.20 \pm 1.45$ \\
\hline MRT (h) & $10.08 \pm 4.38$ & $9.81 \pm 2.21$ \\
\hline \multicolumn{3}{|l|}{ CIPRO } \\
\hline $\mathrm{AUC}_{0-48}(\mu \mathrm{g} \cdot \mathrm{h} / \mathrm{mL})$ & $5.94 \pm 2.41^{\mathrm{a}}$ & $13.33 \pm 2.26^{\mathrm{b}}$ \\
\hline $\operatorname{AUC}_{0-\infty}(\mu \mathrm{g} \cdot \mathrm{h} / \mathrm{mL})$ & $6.04 \pm 2.38^{\mathrm{a}}$ & $13.46 \pm 2.28^{b}$ \\
\hline $\mathrm{C}_{\max }(\mu \mathrm{g} / \mathrm{mL})$ & $0.51 \pm 0.24^{\mathrm{a}}$ & $1.03 \pm 0.25^{\mathrm{b}}$ \\
\hline $\mathrm{T}_{\max }(\mathrm{h})$ & $5.00 \pm 0.00$ & $6.20 \pm 2.40$ \\
\hline MRT (h) & $10.68 \pm 2.35$ & $10.88 \pm 0.84$ \\
\hline
\end{tabular}

${ }^{\mathrm{a}, \mathrm{b}}$ Means within a row with different superscripts differ $(P<0.05)$. ${ }^{1} \mathrm{AUC}$, area under the curve; $\mathrm{C}_{\max }$, maximum concentration; MRT, mean residence time; $\mathrm{T}_{\max }$, time to peak concentration.

als into ovine milk (Pulido et al., 2006; Perez et al., 2013). Overexpression of ABCG2 has recently been associated with in vivo drug resistance in canine multicentric lymphoma (Zandvliet et al., 2015). With regard to genetic variants in animals, previous studies have reported that defective feline ABCG2 is responsible for fluoroquinolone-induced retinal toxicity in cats (Ramirez et al., 2011), and that the bovine ABCG2 Y581S polymorphism alters the yield and composition of milk (Cohen-Zinder et al., 2005; Olsen et al., 2007), and affects the secretion into milk of danofloxacin in cows (Otero et al., 2013, 2015). Wassermann et al. (2013b) predicted that the Y581S polymorphism of the bovine ABCG2 is located in the extracellular area between transmembrane domains 5 and 6 of the transporter. The frequency of this bovine polymorphism can reach $20 \%$ in some Holstein populations but it may be lower in some of them (Ron et al., 2006). Therefore, heterozygosity would be more common than homozygosity for this polymorphism. In this case, the use of heterozygous animals would be the nearest scenario to the real situation (Otero et al., 2015). The present study demonstrated that lactating dairy cows with the Y581S polymorphism showed significantly increased amounts of both ENRO and CIPRO in their milk.

The MDCK-II cells are one of the most commonly used models for studying ABCG2-mediated transport of drugs (Xia et al., 2007). MDCK-II cells overexpressing ABCG2 have shown a strong predictive ability for the effect of ABCG2 on the secretion of drugs into milk (Barrera et al., 2013; Perez et al., 2013; GonzalezLobato et al., 2014). The present in vitro results using MDCK-II cells overexpressing bovine ABCG2 demonstrated for the first time that bovine ABCG2 extrudes and therefore interacts with CIPRO in a specific way 
(Figure 1). As previously shown for ENRO (Real et al., 2011b), cells overexpressing the S581 variant transport CIPRO in the basolateral to apical direction more efficiently than cells with the Y581 variant, indicating a greater in vitro transport capacity for this variant, which is in agreement with the results obtained previously for other drugs such as difloxacin, danofloxacin, marbofloxacin, and nitrofurantoin (Real et al., 2011b; González-Lobato et al., 2014). The results reported here support our in vitro model as a valuable tool for the assessment of bovine ABCG2-mediated transport, but it is not possible to rule out other outcomes if other cell models, such as mammary cell lines, were to be used. In fact, bovine mammary epithelial cells and bovine mammary alveolar cells have previously been used for transport studies (Cavret et al., 2005; Halwachs et al., 2013).

Because of the widespread use of ENRO, it appeared necessary to assess the effect of the bovine Y581S polymorphism on the concentrations in plasma and in milk of ENRO and of CIPRO. Hence, ENRO (Baytril 10\%) was administered to $5 \mathrm{Y} / \mathrm{S} 581$ and $6 \mathrm{Y} / \mathrm{Y} 581$ cows to provide an in vivo setting. The concentrations in plasma recorded for ENRO and CIPRO (Figure 2) were in the same range as those obtained by McKellar et al. (1999) and Fu et al. (2008). With regard to the genotype-driven effect, concentrations in plasma for both compounds were lower for $\mathrm{Y} / \mathrm{S}$ than for $\mathrm{Y} / \mathrm{Y}$ cows. The ABCG2 was first described as a transporter involved in the absorption and excretion of drugs (Jonker et al., 2005). Its expression in the liver, kidney, and intestine of cattle (Zancanella et al., 2013; Lindner et al., 2013; Haslam and Simmons, 2014), together with its induced expression during lactation in the bovine mammary gland (Jonker et al., 2005), have all been confirmed. Thus, the decrease noted in the concentrations in plasma of ENRO in $\mathrm{Y} / \mathrm{S}$ cows is probably due to the enhanced function of the Y581S polymorphism, which may promote a higher clearance of the drug into urine, the primary route for excretion of ENRO (Martinez et al., 2006), into bile, into the intestinal lumen and into milk. However, in the case of CIPRO, the differences between the 2 sets of cows might be attributed not only to an effect of the Y581S polymorphism, but also in part to the metabolism of ENRO, which is converted to CIPRO mainly in the liver (Lopez-Cadenas et al., 2013). Different levels of ENRO were available for metabolizing to CIPRO in the different sets of cows, and the lower concentrations in plasma of CIPRO in $\mathrm{Y} / \mathrm{S}$ cows might be a consequence of lower concentrations in plasma of ENRO in these animals.

With respect to genotype-driven differences in milk parameters, an effect due to the greater transport ca- pacity of the Y581S polymorphism was also observed. Despite lower concentrations in plasma, the higher milk $\mathrm{AUC}_{0-48}$ values in $\mathrm{Y} / \mathrm{S}$ as compared with $\mathrm{Y} / \mathrm{Y}$ animals (Table 1) indicate a higher secretion into milk of ENRO and CIPRO by Y/S cows, similar to the outcome previously reported for danofloxacin by Otero et al. (2013, 2015) after its administration at 2 different dose levels. Although ENRO is mainly metabolized in the liver (Lopez-Cadenas et al., 2013), it is not possible to rule out the possibility that part of the difference observed between the 2 genotypes in the secretion into milk of CIPRO might be due to a partial metabolization of ENRO to CIPRO in the udder (Malbe et al., 1996). However, the much greater differences between $\mathrm{Y} / \mathrm{S}$ and $\mathrm{Y} / \mathrm{Y}$ cows in $\mathrm{AUC}_{0-48}$ for $\mathrm{CIPRO}$ (2.2 times higher), as compared with ENRO (1.2 times higher; Table 1) indicate a striking effect of the Y581S polymorphism on the secretion of CIPRO into milk, regardless of any potential ENRO metabolism in the udder.

Independently of the genotype, the antimicrobial profile in milk after the administration of $\mathrm{ENRO}$ was mainly dominated by CIPRO (Figure 3). Milk $\mathrm{AUC}_{0-48}$ values for CIPRO were higher than for ENRO (5 times higher for $\mathrm{Y} / \mathrm{Y}$ animals and 9 times higher for $\mathrm{Y} / \mathrm{S}$ animals, Table 1), showing that CIPRO was more efficiently accumulated in cow milk than was ENRO. Such higher amounts in milk of CIPRO relative to ENRO have been reported previously (Kaartinen et al., 1995; Rantala et al., 2002; Idowu et al., 2010). Thus, in the case of mastitis, CIPRO would be the key molecule acting against the infectious agent. Moreover, the $\mathrm{C}_{\max }$ values obtained for milk (Table 1, Figure 3) were higher than the in vitro MIC for isolates from mastitis (Grobbel et al., 2007; Thomas et al., 2015). Bearing in mind that the MIC values of ENRO and CIPRO for many pathogens have been reported to be $<0.1 \mu \mathrm{g} / \mathrm{mL}$ (Prescott and Yielding, 1990), if this concentration (0.1 $\mu \mathrm{g} / \mathrm{mL}$ ) is taken as the MIC of these compounds, the therapeutic $\mathrm{C}_{\max } / \mathrm{MIC}$ ratios can be estimated using the milk parameters for the active metabolite CIPRO (Table 1), which highlight an increase from 5.1 in $\mathrm{Y} / \mathrm{Y}$ to 10.3 in $\mathrm{Y} / \mathrm{S}$ animals, respectively. The $\mathrm{C}_{\max } / \mathrm{MIC}$ is important in determining successful outcomes, and in particular, killing the more resistant subpopulations of bacteria (Escudero et al., 2007). Previous research has shown that for fluoroquinolones a $\mathrm{C}_{\max } / \mathrm{MIC}>3$ produced a $99 \%$ reduction in bacterial counts and a $\mathrm{C}_{\max } / \mathrm{MIC}$ of 8 or greater prevented the emergence of resistant organisms (Craig, 1998). The data reported here may be relevant in the therapeutic use of these compounds because prevention of the development of resistance is correlated with the $\mathrm{C}_{\max } / \mathrm{MIC}$ ratio (AliAbadi and Lees, 2000). 


\section{CONCLUSIONS}

This work demonstrates that lactating dairy cows carrying the Y581S polymorphism produced milk with higher amounts of both ENRO and CIPRO. However, the effect of this polymorphism may not be restricted only to fluoroquinolones because other ABCG2 substrate drugs might also be affected. The findings of this study provide evidence that genetic factors such as this polymorphism must be taken into account when designing appropriate veterinary therapies because they can alter the expected drug profile in plasma and milk and may lead to the failure of treatments or to variable amounts of drugs in milk.

\section{ACKNOWLEDGMENTS}

This study was supported by the Spanish Ministry of Economy and Competitiveness (Madrid, Spain) and the European Regional Development Fund (Research Project AGL2012-31116 and AGL2015-65626-R), and the Basque Government in Vitoria, Spain (pre-doctoral fellowship). The authors thank Garfi SAT farm (Santa Maria del Monte del Condado, Province of Leon, Spain) for technical assistance and support. The authors are grateful to the Professional Translation Services of University of Leon for assistance in language editing.

\section{REFERENCES}

AliAbadi, F. S., and P. Lees. 2000. Antibiotic treatment for animals: Effect on bacterial population and dosage regimen optimisation. Int. J. Antimicrob. Agents 14:307-313.

Ballent, M., A. Lifschitz, G. Virkel, J. Sallovitz, L. Maté, and C. Lanusse. 2012. In vivo and ex vivo assessment of the interaction between ivermectin and danofloxacin in sheep. Vet. J. 192:422-427.

Barrera, B., L. González-Lobato, J. A. Otero, R. Real, J. G. Prieto, A. I. Álvarez, and G. Merino. 2013. Effects of triclabendazole on secretion of danofloxacin and moxidectin into the milk of sheep: Role of triclabendazole metabolites as inhibitors of the ruminant ABCG2 transporter. Vet. J. 198:429-436.

Bruhn, O., and I. Cascorbi. 2014. Polymorphisms of the drug transporters $\mathrm{ABCB} 1, \mathrm{ABCG} 2, \mathrm{ABCC} 2$ and $\mathrm{ABCC} 3$ and their impact on drug bioavailability and clinical relevance. Expert Opin. Drug Metab. Toxicol. 10:1337-1354.

Cavret, S., C. Feidt, Y. Le Roux, and F. Laurent. 2005. Study of mammary epithelial role in polycyclic aromatic hydrocarbons transfer to milk. J. Dairy Sci. 88:67-70.

Cohen-Zinder, M., E. Seroussi, D. M. Larkin, J. J. Loor, A. Evertsvan der Wind, J. H. Lee, J. K. Drackley, M. R. Band, A. G. Hernandez, M. Shani, H. A. Lewin, J. I. Weller, and M. Ron. 2005. Identification of a missense mutation in the bovine $A B C G 2$ gene with a major effect on the QTL on chromosome 6 affecting milk yield and composition in Holstein cattle. Genome Res. 15:936-944.

Craig, W. A. 1998. Pharmacokinetic/pharmacodynamic parameters: Rationale for antibacterial dosing of mice and men. Clin. Infect. Dis. 26:1-10.

Escudero, E., C. M. Cárceles, E. Fernandez-varon, P. Marin, and H. Benchaoui. 2007. Pharmacokinetics of danofloxacin $18 \%$ in lactating sheep and goats. J. Vet. Pharmacol. Ther. 30:572-577.
Fu, L. X., Z. G. Jiang, H. Z. Ding, and Y. H. Liu. 2008. Population pharmacokinetics of enrofloxacin and its active metabolite ciprofloxacin in ill cows. J. Vet. Pharmacol. Ther. 31:240-245.

González-Lobato, L., R. Real, D. Herrero, A. de la Fuente, J. G. Prieto, M. M. Marqués, A. I. Alvarez, and G. Merino. 2014. Novel in vitro systems for prediction of veterinary drug residues in ovine milk and dairy products. Food Addit. Contam. Part A Chem. Anal. Control Expo. Risk Assess. 31:1026-1037.

Grobbel, M., A. Lübke-Becker, L. H. Wieler, R. Froyman, S. Friederichs, and S. Filios. 2007. Comparative quantification of the in vitro activity of veterinary fluoroquinolones. Vet. Microbiol. 124:73-81.

Halwachs, S., L. Wassermann, S. Lindner, C. Zizzadoro, and W. Honscha. 2013. Fungicide prochloraz and environmental pollutant dioxin induce the ABCG2 transporter in bovine mammary epithelial cells by the arylhydrocarbon receptor signaling pathway. Toxicol. Sci. 131:491-501.

Haslam, I. S., and N. L. Simmons. 2014. Expression of the ABC transport proteins MDR1 (ABCB1) and BCRP (ABCG2) in bovine rumen. J. Comp. Physiol. B 184:673-681.

Idowu, O. R., J. O. Peggins, R. Cullison, and J. Bredow. 2010. Comparative pharmacokinetics of enrofloxacin and ciprofloxacin in lactating dairy cows and beef steers following intravenous administration of enrofloxacin. Res. Vet. Sci. 89:230-235.

Ito, N., K. Ito, Y. Ikebuchi, T. Kito, H. Miyata, Y. Toyoda, T. Takada, A. Hisaka, H. Honma, A. Oka, H. Kusuhara, and H. Suzuki. 2014 Organic cation transporter/solute carrier family 22a is involved in drug transfer into milk in mice. J. Pharm. Sci. 103:3342-3348.

Jani, M., C. Ambrus, R. Magnan, K. T. Jakab, E. Beery, J. K. Zolnerciks, and P. Krajcsi. 2014. Structure and function of BCRP, a broad specificity transporter of xenobiotics and endobiotics. Arch. Toxicol. 88:1205-1248.

Jonker, J. W., G. Merino, S. Musters, A. E. van Herwaarden, E. Bolscher, E. Wagenaar, E. Mesman, T. C. Dale, and A. H. Schinkel. 2005. The breast cancer resistance protein BCRP (ABCG2) concentrates drugs and carcinogenic xenotoxins into milk. Nat. Med. 11:127-129.

Kaartinen, L., M. Salonen, L. Alli, and S. Pyorala. 1995. Pharmacokinetics of enrofloxacin after single intravenous, intramuscular and subcutaneous injections in lactating cows. J. Vet. Pharmacol. Ther. 18:357-362.

Komisarek, J., and Z. Dorynek. 2009. Effect of ABCG2, PPARGC1A, $O L R 1$ and $S C D 1$ gene polymorphism on estimated breeding values for functional and production traits in Polish Holstein-Friesian bulls. J. Appl. Genet. 50:125-132.

Lindner, S., S. Halwachs, L. Wassermann, and W. Honscha. 2013. Expression and subcellular localization of efflux transporter ABCG2/ BCRP in important tissue barriers of lactating dairy cows, sheep and goats. J. Vet. Pharmacol. Ther. 36:562-570.

Lopez-Cadenas, C., M. Sierra-Vega, J. J. Garcia-Vieitez, M. J. DiezLiebana, A. Sahagun-Prieto, and N. Fernandez-Martinez. 2013. Enrofloxacin: Pharmacokinetics and metabolism in domestic animal species. Curr. Drug Metab. 14:1042-1058.

Malbe, M., M. Salonen, W. Fang, T. Oöpik, M. Jalakas, M. Klaassen, and M. Sandholm. 1996. Disposition of enrofloxacin (Baytril) into the udder after intravenous and intra-arterial injections into dairy cows. J. Vet. Med. A 43:377-386.

Mani, O., M. T. Sorensen, K. Sejrsen, R. M. Bruckmaier, and C. Albrecht. 2009. Differential expression and localization of lipid transporters in the bovine mammary gland during the pregnancylactation cycle. J. Dairy Sci. 92:3744-3756.

Martinez, M., P. McDermott, and R. Walker. 2006. Pharmacology of the fluoroquinolones: A perspective for the use in domestic animals. Vet. J. 172:10-28.

McKellar, Q., I. Gibson, A. Monteiro, and M. Bregante. 1999. Pharmacokinetics of enrofloxacin and danofloxacin in plasma, inflammatory exudate, and bronchial secretions of calves following subcutaneous administration. Antimicrob. Agents Chemother. 43:1988-1992.

Mealey, K. L. 2012. ABCG2 transporter: Therapeutic and physiologic implications in veterinary species. J. Vet. Pharmacol. Ther. $35: 105-112$. 
Mealey, K. L. 2013. Clinical pharmacology and therapeutics. Vet. Clin. North Am. Small Anim. Pract. 43:xi-xiii.

Merino, G., A. I. Alvarez, M. M. Pulido, A. J. Molina, A. H. Schinkel, and J. G. Prieto. 2006. Breast cancer resistance protein (BCRP/ ABCG2) transports fluoroquinolone antibiotics and affects their oral availability, pharmacokinetics, and milk secretion. Drug Metab. Dispos. 34:690-695.

Moreno-Sanz, G., B. Barrera, A. Armirotti, S. M. Bertozzi, R. Scarpelli, T. Bandiera, J. G. Prieto, A. Duranti, G. Tarzia, G. Merino, and D. Piomelli. 2014. Structural determinants of peripheral Oarylcarbamate FAAH inhibitors render them dual substrates for Abcb1 and Abcg2 and restrict their access to the brain. Pharmacol. Res. 87:87-93.

Olsen, H. G., H. Nilsen, B. Hayes, P. R. Berg, M. Svendsen, S. Lien, and T. Meuwissen. 2007. Genetic support for a quantitative trait nucleotide in the ABCG2 gene affecting milk composition of dairy cattle. BMC Genet. 21:8-32.

Otero, J. A., B. Barrera, A. de la Fuente, J. G. Prieto, M. Marqués, A. I. Álvarez, and G. Merino. 2015. The gain-of-function Y581S polymorphism of the ABCG2 transporter increases secretion into milk of danofloxacin at the therapeutic dose for mastitis treatment. J. Dairy Sci. 98:312-317.

Otero, J. A., R. Real, A. de la Fuente, J. G. Prieto, M. Marques, A. I. Alvarez, and G. Merino. 2013. The bovine ATP-binding cassette transporter ABCG2 Tyr581Ser single-nucleotide polymorphism increases milk secretion of the fluoroquinolone danofloxacin. Drug Metab. Dispos. 41:546-549.

Perez, M., J. A. Otero, B. Barrera, J. G. Prieto, G. Merino, and A. I. Alvarez. 2013. Inhibition of ABCG2/BCRP transporter by soy isoflavones genistein and daidzein: Effect on plasma and milk levels of danofloxacin in sheep. Vet. J. 196:203-208.

Petzinger, E., and J. Geyer. 2006. Drug transporters in pharmacokinetics. Naunyn Schmiedebergs Arch. Pharmacol. 372:465-475.

Prescott, J. F., and K. M. Yielding. 1990. In vitro susceptibility of selected veterinary acterial pathogens to ciprofloxacin, enrofloxacin and norfloxacin. Can. J. Vet. Res. 54:195-197.

Pulido, M. M., A. J. Molina, G. Merino, G. Mendoza, J. G. Prieto, and A. I. Alvarez. 2006. Interaction of enrofloxacin with breast cancer resistance protein (BCRP/ABCG2): Influence of flavonoids and role in milk secretion in sheep. J. Vet. Pharmacol. Ther. $29: 279-287$.

Pyörälä, S. 2009. Treatment of mastitis during lactation. Ir. Vet. J. 62:S40-S44.

Ramirez, C. J., J. D. Minch, J. M. Gay, S. M. Lahmers, D. J. Guerra, G. J. Haldorson, T. Schneider, and K. L. Mealey. 2011. Molecular genetic basis for fluoroquinolone-induced retinal degeneration in cats. Pharmacogenet. Genomics 21:66-75.
Rantala, M., L. Kaartinen, E. Valimaki, M. Stryrman, M. Hiekkaranta, A. Niemi, L. Saari, and S. Pyorala. 2002. Efficacy and pharmacokinetics of enrofloxacin and flunixin meglumine for treatment of cows with experimentally induced Escherichia coli mastitis. J. Vet. Pharmacol. Ther. 25:251-258.

Real, R., E. Egido, M. Perez, L. Gonzalez-Lobato, B. Barrera, J. G. Prieto, A. I. Alvarez, and G. Merino. 2011a. Involvement of breast cancer resistance protein (BCRP/ABCG2) in the secretion of danofloxacin into milk: Interaction with ivermectin. J. Vet. Pharmacol. Ther. 34:313-321.

Real, R., L. Gonzalez-Lobato, M. F. Baro, S. Valbuena, A. de la Fuente, J. G. Prieto, A. I. Alvarez, M. M. Marques, and G. Merino. 2011b. Analysis of the effect of the bovine adenosine triphosphate-binding cassette transporter G2 single nucleotide polymorphism Y581S on transcellular transport of veterinary drugs using new cell culture models. J. Anim. Sci. 89:4325-4338.

Ron, M., M. Cohen-Zinder, C. Peter, J. I. Weller, and G. Erhardt. 2006. Short communication: A polymorphism in ABCG2 in Bos indicus and Bos taurus cattle breeds. J. Dairy Sci. 89:4921-4923.

Schrickx, J. A., and J. Fink-Gremmels. 2008. Implications of ABC transporters on the disposition of typical veterinary medicinal products. Eur. J. Pharmacol. 585:510-519.

Thomas, V., A. de Jong, H. Moyaert, S. Simjee, F. El Garch, I. Morrissey, H. Marion, and M. Vallé. 2015. Antimicrobial susceptibility monitoring of mastitis pathogens isolated from acute cases of clinical mastitis in dairy cows across Europe: VetPath results. Int. J. Antimicrob. Agents 46:13-20.

Virolainen, N., and M. Karp. 2014. Biosensors, antibiotics and food. Adv. Biochem. Eng. Biotechnol. 145:153-185.

Wassermann, L., S. Halwachs, D. Baumann, I. Schaefer, P. Seibel, and W. Honscha. 2013a. Assessment of ABCG2-mediated transport of xenobiotics across the blood-milk barrier of dairy animals using a new MDCKII in vitro model. Arch. Toxicol. 87:1671-1682.

Wassermann, L., S. Halwachs, S. Lindner, K. U. Honscha, and W. Honscha. 2013b. Determination of functional ABCG2 activity and assessment of drug-ABCG2 interactions in dairy animals using a novel MDCKII in vitro model. J. Pharm. Sci. 102:772-784.

Xia, C. Q., M. N. Milton, and L. S. Gan. 2007. Evaluation of drugtransporter interactions using in vitro and in vivo models. Curr. Drug Metab. 8:341-363.

Zancanella, V., M. Giantin, R. M. Lopparelli, C. Nebbia, and M. Dacasto. 2013. Tissue distribution and phenobarbital induction of target SLC- and ABC- transporters in cattle. J. Vet. Pharmacol. Ther. 36:358-369.

Zandvliet, M., E. Teske, J. A. Schrickx, and J. A. Mol. 2015. A longitudinal study of $\mathrm{ABC}$ transporter expression in canine multicentric lymphoma. Vet. J. 205:263-271. 